\title{
Systemic Risk and the Solvency-Liquidity Nexus of Banks*
}

\author{
Diane Pierret \\ University of Lausanne
}

\begin{abstract}
This paper highlights the empirical interaction between solvency and liquidity risks of banks that make them particularly vulnerable to an aggregate crisis. In line with the literature explaining bank runs based on the quality of the bank's fundamentals, I find that banks lose their access to short-term funding when markets expect they will be insolvent in a crisis. This solvency-liquidity nexus is found to be strong under many robustness checks and to contain useful information for forecasting the short-term balance sheet of banks. The results suggest that capital not only acts as a loss-absorbing buffer, but it also ensures the confidence of creditors to continue to provide funding to the banks in a crisis.
\end{abstract}

JEL Codes: G01, G21, G28.

*I am extremely grateful to Viral Acharya, Luc Bauwens, Robert Engle, and Christian Hafner for their excellent guidance and continuous support. I thank Tobias Adrian (discussant), Sophie Béreau, Stephen Cecchetti (discussant), Stephen Figlewski, Harrison Hong, Eric Jondeau, Andres Liberman, Matteo Luciani, Matthew Richardson, Anthony Saunders, Philipp Schnabl, Sascha Steffen, David Veredas, Charles-Henri Weymuller (discussant), research seminar participants at the Bank of Canada, the Bank of England, the Board of Governors of the Federal Reserve, Bonn University, the Federal Reserve of Boston, HEC Lausanne, Warwick Business School, as well as participants of the 6th Annual Volatility Institute Conference, the joint Banque de France - ACPR - SoFiE conference, EFA 2014, AEA 2015, and the 2014 Annual Research Conference of the International Journal of Central Banking for helpful comments. I also thank Rob Capellini for providing me with V-Lab's measures of systemic risk. I gratefully acknowledge financial support from the Sloan foundation, BlackRock, Deutsche Bank, and supporters of the Volatility Institute of the NYU Stern School of Business. All remaining errors are my own. Author contact: Faculty of Business and Economics (HEC Lausanne), University of Lausanne, CH-1015 Lausanne, Switzerland; E-mail: diane.pierret@unil.ch, Tel: +41 216926128. 
"A more interesting approach would be to tie liquidity and capital standards together by requiring higher levels of capital for large firms unless their liquidity position is substantially stronger than minimum requirements. This approach would reflect the fact that the market perception of a given firm's position as counterparty depends upon the combination of its funding position and capital levels.... While there is decidedly a need for solid minimum requirements for both capital and liquidity, the relationship between the two also matters. Where a firm has little need of short-term funding to maintain its ongoing business, it is less susceptible to runs. Where, on the other hand, a firm is significantly dependent on such funding, it may need considerable common equity capital to convince market actors that it is indeed solvent. Similarly, the greater or lesser use of short-term funding helps define a firm's relative contribution to the systemic risk latent in these markets." Tarullo (2013)

\section{Introduction}

The main function of banks is to provide liquidity by offering funding (deposits) that is more liquid than their asset holdings (Diamond and Dybvig 1983). This liquidity mismatch, part of their business model, makes banks vulnerable to runs, as creditors can demand immediate repayment when the bank faces asset shocks. The rationale for studying the solvency-liquidity nexus of banks is based on the literature explaining bank runs based on the strength of the bank's fundamentals. In Allen and Gale (1998), banking panics are related to the business cycle where creditors run if they anticipate that the bank's asset values will deteriorate. Similarly, Gorton (1988) shows that bank runs are systematic responses to the perceived risk of banks.

Theoretical models on the two-way interaction between solvency and liquidity have been more recently developed. Diamond and Rajan (2005) show that bank runs, by making banks insolvent, exacerbate aggregate liquidity shortages. In Rochet and Vives (2004), there is an intermediate range of the bank assets value for which the bank is still solvent but can fail if too many of its creditors withdraw, and the range of the interval decreases with the strength of the bank's fundamentals. Then, Morris and Shin (2008) explain that bank runs come from both the bank's weak fundamentals and the 
"jitteriness" of its creditors. Therefore, the failure region of the bank would be smaller if both the bank and its creditors held more cash.

An implication of this literature is that systemic risk is likely to play a key role in the solvency-liquidity nexus through the liquidation costs caused by fire sales in a crisis. If the firm fails in isolation, its illiquid assets can be liquidated for a price close to their value in best use (Shleifer and Vishny 1992) 1 In a systemic crisis, however, potential buyers will be unable to find funding to buy the assets of the distressed firm. Creditors will consequently run from banks that are vulnerable to an aggregate shock, as they anticipate these banks will not be able to repay them in a crisis.

While the solvency-liquidity nexus has been well studied theoretically in the economic literature, the interaction between solvency and liquidity risks tends to be omitted in the new capital and liquidity regulatory standards. The liquidity coverage ratio (LCR) of Basel III imposes that financial firms hold a sufficient amount of highquality liquid assets to cover their liquidity needs over a month of stressed liquidity scenario 2 However, the liquidity needs according to this standard are essentially a function of the funding mix of the bank and do not depend on other bank's fundamentals - in particular, on its capital adequacy and asset risks. Similarly, the required capitalization of a bank is not related to its exposure to funding liquidity risk 3

\footnotetext{
${ }^{1}$ Other fire-sale papers also relying on the Shleifer and Vishny (1992) insight include Acharya and Yorulmazer (2008); Acharya and Viswanathan (2011); Allen and Gale (1998, 2000a, 2000b, 2004); and Diamond and Rajan (2005, 2011).

${ }^{2}$ Next to the LCR, Basel III also introduces a net stable funding ratio (NSFR). The NSFR is the ratio of available stable funding to required stable funding over a one-year horizon. The required stable funding is determined based on the institution's assets and activities (Basel Committee on Banking Supervision 2011).

${ }^{3}$ Funding liquidity risk is only likely to play a modest role via the interconnectedness measure used to derive the additional capital requirement for globally systemically important financial institutions (G-SIFIs). The systemic importance measure is the equally weighted average of the size, interconnectedness, lack of substitutes for the institution's services, global activity, and complexity (Basel Committee on Banking Supervision 2013b). Interconnectedness is itself based on three indicator measures: intrafinancial system assets, intrafinancial system liabilities, and securities outstanding. Alternatively, some supervisory stress-test models explicitly feature funding liquidity feedbacks from the deterioration of the banks' fundamentals as in the risk assessment model for systemic institutions (RAMSI) of Aikman et al. (2009) used at the Bank of England.
} 
The solvency-liquidity nexus of banks has also not been the center of empirical studies investigating funding liquidity risk of the financial sector 4 In this paper, I fill this gap in the literature and test whether the solvency-liquidity nexus of banks empirically holds by examining the short-term balance sheet of fifty U.S. bank holding companies over 2000-13. Short-term debt mainly consists of federal funds purchased and repurchase agreements (repos), uninsured deposits, and other short-term borrowings. Short-term assets include cash, federal funds sold and reverse repos, and short-term debt securities.

The difference between short-term debt and short-term assets is used in this paper as a proxy for the exposure of a firm to funding liquidity risk. Funding liquidity risk arises when a financial firm cannot roll over its existing short-term debt and/or raise new short-term debt. When the bank's short-term funding starts drying up, the firm needs a sufficient amount of liquid assets that can be converted into cash to repay creditors. The gap between its short-term debt and short-term assets is called the liquid asset shortfall. A negative liquid asset shortfall (liquidity excess) represents the amount of liquid assets that would be left if the bank lost its complete access to shortterm funding (see figure 1 for a simplified view of the balance sheet of a bank).

I test for the solvency-liquidity nexus using several measures of solvency risk: regulatory capital ratios, market measures of risk (realized volatility, market beta), and a measure of the expected capital shortfall $(S R I S K)$ of the bank under aggregate stress defined by Acharya et al. (2010), Acharya, Engle, and Richardson (2012), and Brownlees and Engle (2011). According to SRISK, a firm is adequately capitalized to survive a crisis if its ratio of market capitalization to total assets remains larger than 8 percent when the market

\footnotetext{
${ }^{4}$ Related empirical studies include Das and Sy (2012), who document the trade-off between solvency and liquidity; banks with more stable funding and more liquid assets do not need as much capital to get the same stock return. Gorton and Metrick (2012) find that increases in repo rates are correlated to higher aggregate counterparty risk, whereas increases in repo haircuts are correlated to higher uncertainty about collateral values. Afonso, Kovner, and Schoar (2011) study the federal funds market and find increased sensitivity to bankspecific counterparty risk during times of crisis (both in the amounts lent to borrowers and in the cost of overnight funds).
} 


\section{Figure 1. Simplified Balance Sheet}

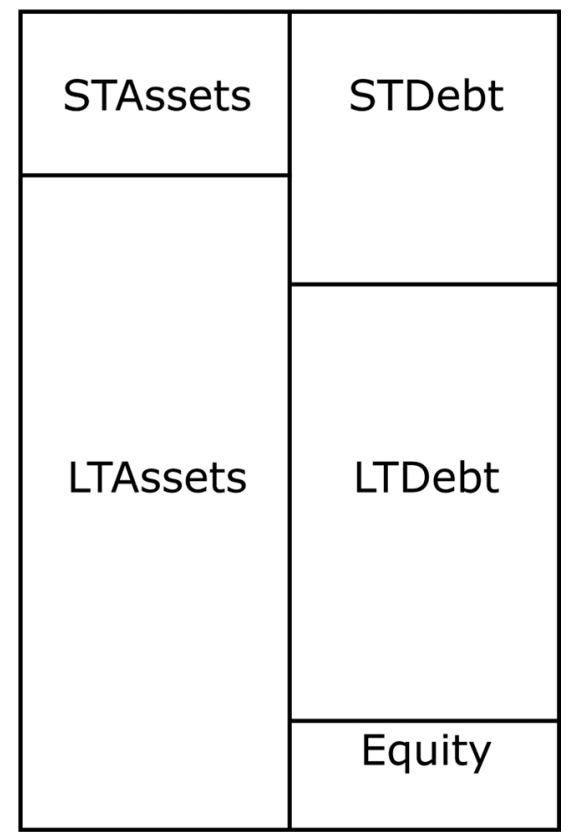

Notes: Liquid asset shortfall $_{i t}=S T$ Debt $_{i t}-S T A s s e t s_{i t}$. Capital shortfall it $_{i t}=$ $k *\left(\right.$ ST Assets $_{i t}+$ LTAssets $\left._{i t}\right)-$ Equity $_{i t}$. Expected capital shortfall in a crisis $S R I S K_{i t}=\mathrm{E}\left[k *\left(\right.\right.$ STAssets $_{i t+h}+$ LTAssets $\left._{i t+h}\right)-$ Equity $_{i t+h} \mid$ crisis $\left._{t+h}\right]=$ $k *\left(\right.$ LTDebt $_{i t}+S T$ Debt $\left._{i t}\right)-(1-k) *$ Equity $_{i t} *\left(1+\mathrm{E}\left(R_{i t+h} \mid\right.\right.$ crisis $\left.\left._{t+h}\right)\right)$, where $k$ is the prudential capital ratio (8 percent).

index falls by 40 percent over the next six months. This measure is an alternative to the capital shortfall estimates of regulatory stress tests that is purely based on publicly available market data (and therefore available at a higher frequency than stress-test outcomes).

I document three important results. First, I find that the bank's capital shortfall under stress (SRISK) determines how much shortterm debt it can raise. This result supports the models of Allen and Gale (1998), Diamond and Rajan (2005), etc. explaining bank runs based on the strength of the bank's fundamentals. The consequences of this solvency-liquidity nexus are particularly severe for banks that are reliant on private short-term funding, in line with the introductory quote of D. Tarullo and some previous evidence that firms with more maturity mismatch have a larger contribution to systemic 


\section{Figure 2. Cross-Sectional Average of Liquid Asset Shortfall: Capital-Constrained Banks (Black Line) vs. Adequately Capitalized Banks (Dashed Line)}

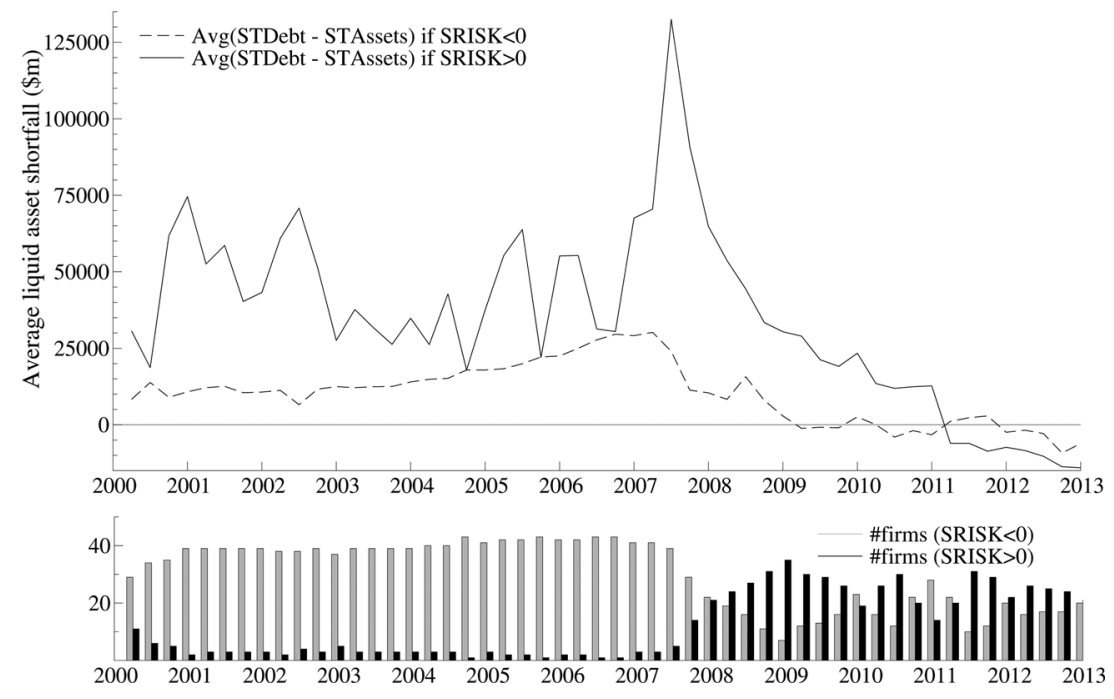

Notes: Liquid asset shortfall $=$ Short-term debt - Short-term assets ( $\$$ million). "Adequately capitalized" means $S R I S K_{i t} \leq 0$.

risk (Adrian and Brunnermeier 2010). Figure 2 illustrates well the solvency-liquidity nexus where capital-constrained banks (i.e., banks with a positive SRISK) had a larger average exposure to liquidity risk (measured by the difference between short-term debt and shortterm assets) than adequately capitalized banks before the financial crisis. The average liquidity shortfall of capital-constrained banks reached a maximum of $\$ 133$ billion in the third quarter of 2007 . This exposure made them particularly vulnerable to the sudden freeze of short-term funding markets that followed.

Second, I show that not all solvency risk measures predict the short-term debt level of banks. The expected capital shortfall SRISK interacts well with the level of short-term funding of the bank compared with other measures of solvency risk because (i) it is a measure of the bank's exposure to aggregate risk, and (ii) it combines both book and market values. Relating to the model of liquidation costs of Shleifer and Vishny (1992), result (i) suggests that a bank with higher solvency risk in isolation does not necessarily get restricted 
access to short-term funding. What matters most for the suppliers of short-term funding is the vulnerability of the bank to an aggregate crisis. When this crisis occurs, result (ii) suggests that "pure" solvency risk (measured by the tier 1 leverage ratio), amplified by market shocks, explains the bank's access to short-term funding.

Third, the stressed solvency risk measure interacts with the bank's profitability (measured by its net income divided by total assets) in determining its short-term balance sheet. While a more profitable bank has greater access to short-term funding and does not hold as much in liquid assets, profitability does not have this beneficial effect on its short-term balance sheet when the bank is expected to be capital constrained in a crisis. For example, the positive net income of $\$ 2$ billion of Citigroup in the third quarter of 2007 did not prevent the bank from losing 18 percent of its shortterm funding ( $-\$ 172$ billion) the next quarter, as Citigroup was also highly undercapitalized according to SRISK (\$51 billion expected capital shortfall in 2007:Q3). Therefore, maintaining a certain level of capitalization of the banking sector reduces systemic risk not only by addressing solvency risk problems of banks in a crisis but also by attenuating the solvency-liquidity nexus that makes banks particularly vulnerable to an aggregate crisis.

Finally, the solvency-liquidity nexus appears to be strong under many robustness checks (controlling for government interventions and common factors). Furthermore, out-of-sample forecasting results during the European sovereign debt crisis show that the solvencyliquidity interaction helps improve the forecasts of the short-term balance sheet of banks. Omitting SRISK in the model increases the forecasting errors of the liquid asset shortfall considerably, and particularly for capital-constrained banks.

Overall, the results of this paper suggest that the solvencyliquidity nexus should be accounted for when designing liquidity and capital requirements. The paper gives empirical support to the approach advanced by Tarullo (2013) to tie liquidity and capital requirements together by requiring banks with a large exposure to short-term funding to hold an additional capital buffer. The liquid asset buffer of the LCR might be a sufficient requirement from a microprudential perspective. However, the sudden drop in short-term funding for a bank that has a perfectly maturity-matched securities book (including repos and reverse repos) may also result in 
fire sales and increases the risk of contagion by transferring funding liquidity risk to the bank's customers. The supplementary capital buffer is a preemptive measure that would give creditors the confidence to continue to provide funding to the bank in a period of aggregate stress.

The rest of the paper is structured as follows. In section 2, I describe the short-term balance sheet of banks and their solvency risk measures. I test the solvency-liquidity nexus in section 3. I comment on the out-of-sample forecasting results in section 4, and conclude in section 5 .

\section{Short-Term Balance Sheet and Solvency Risk Measures}

I define solvency risk and (funding) liquidity risk from the simplified representation of a bank's balance sheet in figure 1. A bank will be considered insolvent if it is not sufficiently capitalized to absorb future asset shocks. Solvency risk regulation defines the fraction of assets to be funded with equity such that a bank has a large-enough equity capital buffer to absorb asset losses when asset values deteriorate. As a result, a measure of solvency risk is usually defined as a measure of the bank's equity capital relative to a measure of its assets.

Next to solvency risk, funding liquidity risk is defined in Drehman and Nikolaou (2013) as "the possibility that over a specific horizon the bank will become unable to settle obligations with immediacy." Funding liquidity risk typically arises when the bank does not hold enough liquid assets that can be easily converted into cash to repay short-term creditors when they decide to withdraw. Liquidity regulation therefore ensures that the bank has a large-enough liquid asset buffer to cover all funding outflows over a given horizon.

Funding liquidity risk is related to the maturity mismatch of a bank that invests short-term funding in long-term assets. For the bank depicted in figure 1, a proxy for its maturity mismatch is the difference between its short-term debt and its short-term assets. The gap between the short-term debt and the short-term assets of a bank is called its liquid asset shortfall throughout, as I expect a bank with a larger maturity mismatch to be more exposed to funding liquidity risk. On the liability side, short-term creditors will be the first 
creditors to run, as they can simply decide not to roll over their short-term funding contracts. On the asset side, short-term assets are potentially the largest source of cash of the balance sheet 5

\subsection{Long-Term vs. Short-Term Balance Sheet and the Liquid Asset Shortfall}

The sample considered in this paper is a panel of forty-nine publicly traded U.S. bank holding companies (BHCs) reporting their regulatory accounting data over thirteen years from 2000:Q1 until 2013:Q1 (i.e., fifty-three quarters). This sample of banks corresponds to the intersection between the New York University Volatility Laboratory (V-Lab) sample for its global systemic risk analysis (that will be introduced in the next section), and the bank holding companies reporting under the FR Y-9C schedule (equivalent to the Call Reports of Condition and Income of commercial banks). The names of the BHCs and their market capitalizations are reported in the online appendix (appendix 5) on the $I J C B$ website (http://www.ijcb.org).

I construct the short-term debt and short-term asset variables of these BHCs based on items extracted from their FR Y-9C reports from the SNL Financial database. The short-term debt is made up of uninsured time deposits of remaining maturity of less than a year, securities sold under agreements to repurchase (repos), federal funds purchased, and other borrowed money of remaining maturity of less than a year. The short-term assets include debt securities of remaining maturity of less than a year, interest-bearing bank balances (cash), securities purchased under agreements to resell (reverse repos), and federal funds sold. The components of short-term debt and short-term assets are described in appendix 1.

\footnotetext{
${ }^{5}$ Short-term assets will serve in this chapter as a proxy for liquid assets due to the lack of historical data for the assets included in the high-quality liquid assets (HQLA) definition of Basel III. High-quality liquid assets include cash, reserves at central banks, Treasury bonds, and non-financial corporate bonds and covered bonds with the highest ratings. Additional assets like highly rated residential mortgage-backed securities, non-financial corporate bonds and covered bonds with $[\mathrm{A}+, \mathrm{BBB}-]$ rating, and common equity shares can be included in the HQLA stock with the appropriate haircuts specified in the LCR revision of 2013 (Basel Committee on Banking Supervision 2013a).
} 
As the panel data set is unbalanced, I will restrict the following analyses to a smaller sample of forty-four banks for which the timeseries dimension is larger than thirty observations 6 I test the stationarity of the balance sheet quantities (in logarithms) in appendix 2 , using the panel unit-root test robust to cross-sectional dependence of Pesaran (2007). This test indicates that the permanent impact of a shock on the size (measured by total assets) of a bank comes from shocks in the long-term balance sheet (where the unit-root hypothesis is not rejected), whereas the short-term balance sheet shocks revert to a trend level. 7 This result is consistent with the long-term balance sheet being the core business of the traditional bank that invests insured deposits (part of the long-term debt) in loans (long-term assets) 8

The evolution of the average balance sheet of banks is shown in figure 3 . The average size of the balance sheet (total assets) triples (from $\$ 85$ billion to $\$ 280$ billion) over the sample period and follows an increasing trend in the long-term balance sheet. Over this period, and particularly during the financial crisis, salient events include the acquisition of out-of-sample banks by in-sample banks (Golden West Financial sold to Wachovia in May 2006, Bear Stearns sold to JPMorgan in March 2008, Countrywide sold to Bank of America in July 2008, Washington Mutual sold to JPMorgan and Merrill Lynch sold to Bank of America in September 2008) and the acquisition of in-sample banks by other in-sample banks (National City Corp. sold to PNC and Wachovia sold to Wells Fargo in the last quarter of 2008).

For the purpose of testing the solvency-liquidity nexus, this paper focuses on the short-term part of the balance sheet. The acquisition of two major investment banks (Bear Stearns and Merrill Lynch) in 2008 brought a considerable amount of short-term

\footnotetext{
${ }^{6}$ This restriction excludes Goldman Sachs and Morgan Stanley from the sample, as they obtained the status of bank holding company at the end of 2008. The restriction also excludes American Express, CIT Group, and Discover Financial Services.

${ }^{7}$ The trend stationarity of the short-term balance sheet allows for estimating a dynamic panel data model directly on the levels in section 3, by applying standard estimation and inference techniques.

${ }^{8}$ The long-term debt (respectively, assets) is the difference between total liabilities (respectively, assets) and short-term debt (respectively, assets).
} 


\section{Figure 3. Cross-Sectional Averages of the Balance Sheet (in \$million)}

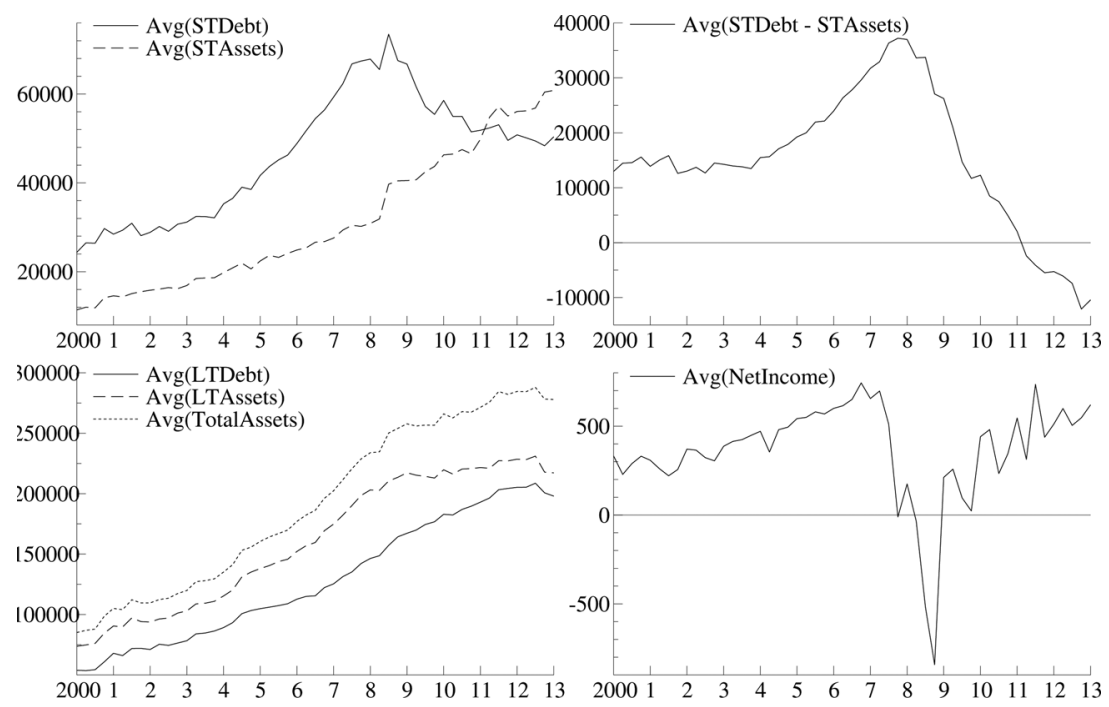

Notes: Top-left graph: short-term debt and short-term assets. Top-right graph: the difference between short-term debt and short-term assets. Bottom-left graph: total assets and long-term balance sheet. Bottom-right graph: net income.

debt and short-term assets into the banking sector. The increase in the average short-term balance sheet is considerable with the purchase of Bear Stearns (visible on JPMorgan's balance sheet in 2008:Q3). In comparison, the impact of the acquisition of Merrill Lynch (visible on Bank of America's balance sheet in 2009:Q1) on the average short-term balance sheet is attenuated, as several large banks were losing a significant amount of short-term funding at that time.

In contrast to an overall increasing trend in short-term assets, the average short-term debt slowed down in 2007:Q3 with the first signs of a "run on repo" in August 2007 (Gorton and Metrick 2012), visible on the short-term balance sheet of several large banks, including Citigroup, which lost $\$ 172$ billion (18 percent) of short-term debt from 2007:Q3 to 2007:Q4. The average short-term debt of U.S. BHCs reached a peak in the third quarter of 2008 (with the acquisition of Bear Stearns) and declined afterwards. 
The average liquid asset shortfall of the banking sector (the average of the difference between short-term debt and short-term assets) was the largest at the end of 2007 (also shown in figure 3), making banks particularly vulnerable to the sudden freeze in short-term funding markets. The short-term funding freeze was further accentuated by credit risk concerns at the end of 2008 with Lehman Brothers' bankruptcy and the most negative average net income of banks over the sample period ( $\$ 850$ million).

Since the financial crisis, the average liquid asset shortfall of banks has declined, becoming negative in 2011 (i.e., banks now hold more short-term assets than short-term debt). Several circumstances explain the increase of banks' stock of short-term assets. A first explanation is linked to the persistent effect of the financial crisis on the real economy where the demand for loans has been slowly recovering and has been outpaced by deposit growth. As a result, banks have been investing in securities and (profitable) Treasury products 9 In order to obtain secured short-term funding, banks also need to hold more short-term liquid assets than before due to stricter collateral requirements (higher haircuts). Then, higher liquid asset holdings by banks respond to precautionary concerns by banks (protecting against anticipated interest rate increase) and the regulator. Banks are encouraged by regulation to hold more short-term liquid assets to comply with both liquidity requirements (Basel III liquidity coverage ratio) and capital requirements (as holding short-term assets usually involves low regulatory capital requirements).

\subsection{Solvency Risk Measures}

\subsubsection{Regulatory Capital Ratios}

The regulator usually employs capital ratios to assess the solvency risk of a bank. Figure 4 displays the average regulatory capital ratios: the tier 1 common capital ratio $(T 1 C R)$ and the tier 1 leverage ratio $(T 1 L V G R)$. The tier 1 common capital ratio is the ratio of tier 1 common equity capital to risk-weighted assets, whereas the tier 1 leverage ratio is the ratio of tier 1 capital to total assets. The upward

\footnotetext{
${ }^{9}$ See "U.S. Banks Brace for Interest Rate Rises," Financial Times, February 24, 2011, and "Excess Deposits Demand Novel Responses," Financial Times, May 30, 2012.
} 


\section{Figure 4. Cross-Sectional Averages of Solvency Risk Measures}

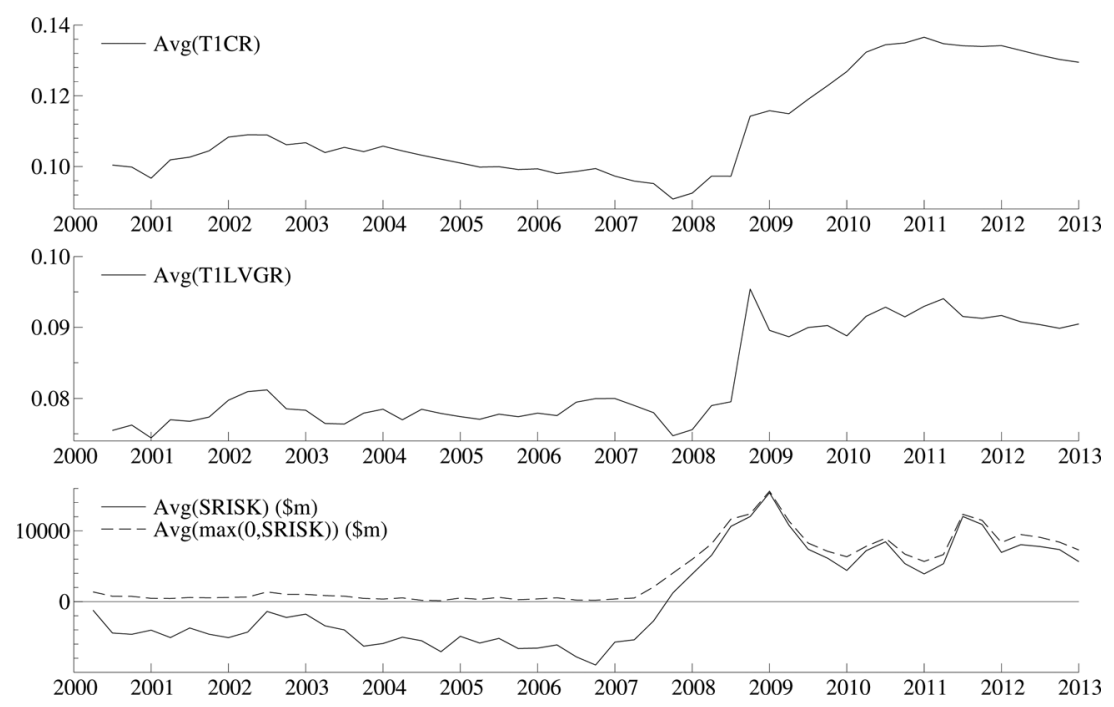

Notes: $T 1 C R$ is the tier 1 common capital ratio (tier 1 common capital divided by risk-weighted assets); T $1 L V G R$ is the tier 1 leverage ratio (tier 1 capital divided by total assets); SRISK is the expected capital shortfall in a crisis.

shift in regulatory capital ratios in the fourth quarter of 2008 indicates a healthier banking system and coincides with the launch on October 14, 2008 of the Capital Purchase Program (CPP) and the Temporary Liquidity Guarantee Program (TLGP) under the Troubled Asset Relief Program (TARP). By purchasing assets and equity from troubled banks from October 2008 on, the TARP led to a significant increase in the average capital ratios. For example, Treasury bought $\$ 25$ billion of preferred shares of Citigroup in October 2008 and another $\$ 20$ billion in November 2008 under the CPP 10

\subsubsection{Expected Capital Shortfalls in a Crisis}

Acharya, Engle, and Richardson (2012) define the systemic risk contribution of a firm $i$ to the real economy at time $t$ as "the real social

\footnotetext{
${ }^{10}$ See http://www.treasury.gov/initiatives/financial-stability/reports/Pages/ TARP-Tracker.aspx.
} 
costs of a crisis per dollar of capital shortage $(t) \times$ Probability of a crisis $(t) \times S R I S K_{i t}$," where $S R I S K_{i t}$ represents the expected capital shortfall of the firm in a crisis, i.e., when the market equity index drops by 40 percent over the next six months. In these market conditions, SRISK is based on the assumption that the book value of the (long-term) debt $D_{i t}$ of the bank will remain constant over the six-month horizon, while its market capitalization $M V_{i t}$ will decrease by its six-month return in a crisis, called the long-run marginal expected shortfall ( $L R M E S)$. The expected capital shortfall in a crisis of bank $i$ at time $t$ is defined by

$$
\begin{aligned}
S R I S K_{i t} & =\mathrm{E}_{t}\left[k\left(D_{i t+h}+M V_{i t+h}\right)-M V_{i t+h} \mid R_{m t+h} \leq-40 \%\right] \\
& =k D_{i t}-(1-k) * M V_{i t} *\left(1-L R M E S_{i t}\right),
\end{aligned}
$$

where $R_{m t+h}$ is the return of the market index from period $t$ to period $t+h$ ( $h=$ six months), $k$ is the prudential capital ratio (8 percent for U.S. financial firms), and $L R M E S_{i t}=-\mathrm{E}_{t}\left(R_{i t+h} \mid R_{m t+h} \leq\right.$ $-40 \%)$. Compared to other market-based measures of systemic risk like the CoVaR of Adrian and Brunnermeier (2010) or the distress insurance premium (DIP) of Huang, Zhou, and Haibin (2012), an interesting feature of $S R I S K$ is that it is a function of size and leverage, which are two characteristics that the regulator finds particularly relevant when measuring solvency risk of banks. SRISK can be written as a function of size, leverage, and risk:

$$
S R I S K_{i t}=M V_{i t}\left\{k\left(\operatorname{Lvg}_{i t}-1\right)-(1-k)\left(1-L R M E S_{i t}\right)\right\},
$$

where $L v g_{i t}$ is the quasi-market leverage defined as the ratio of quasimarket assets to market capitalization $\left(L v g_{i t}=\left(M V_{i t}+D_{i t}\right) / M V_{i t}\right)$. Therefore, the capital shortfall of a bank will be large if the bank is large, highly leveraged, and highly sensitive to an aggregate shock as measured by $L R M E S_{i t}$.

These measures (SRISK and LRMES) are available from the V-Lab website developed at New York University's Stern School of Business 11 In the global systemic risk analysis of V-Lab, LRMES is extrapolated from its short-term counterpart $M E S$, which represents the daily return of the bank conditional on a 2 percent decline

\footnotetext{
${ }^{11}$ See http://vlab.stern.nyu.edu/.
} 
in the daily return of a global market index. The $M E S$ is derived from a time-varying beta estimated with the dynamic conditional beta model of Engle (2012) that accounts for asynchronous trading around the world when measuring the co-movement of bank returns with a global market index.

By definition, SRISK can be negative when a bank is expected to have a capital excess in a crisis. In figure 4 , we find two different regimes for the average $S R I S K$ of banks. Banks were in excess of capital in average (negative $S R I S K$ ) before 2007. The average $S R I S K$ was the lowest in the third quarter of 2006 , then started to increase in 2007. SRISK became positive in the fourth quarter of 2007 and reached a maximum average capital shortfall of $\$ 16$ billion in the first quarter of 2009. The average capital shortfall has remained positive since the financial crisis (reflecting a low marketto-book ratio) and bumped several times afterwards, in particular in the heat of the European sovereign debt crisis in 2011.

\section{Testing the Solvency-Liquidity Nexus of Banks}

As liquidity risk concerns both sides of the balance sheet, I test for factors affecting both the short-term debt and the short-term assets of the bank. I use an autoregressive model for the logarithm of the short-term balance sheet, as panel unit-root tests indicate that the variables $y_{i t}=\ln \left(S T\right.$ Debt $\left._{i t}\right)$ and $z_{i t}=\ln \left(S T\right.$ Asset $\left._{i t}\right)$ are trend stationary (see appendix 2). Based on in-sample fit criteria, the model for both elements of $w_{i t}=\left(y_{i t}, z_{i t}\right)^{\prime}$ is an autoregressive process of lag order one with bank dummies, and heterogeneous trend and dynamic parameters

$$
w_{i t}=\alpha_{i}+\phi_{i} \odot w_{i t-1}+\theta_{i} t+\delta^{\prime} x_{i t-1}+\varepsilon_{i t},
$$

where $\alpha_{i}, \phi_{i}$, and $\theta_{i}$ are $(2 \times 1)$ vectors of parameters specific to bank $i, x_{i t}$ is a $(K \times 1)$ vector of stationary bank characteristics (including solvency risk measures), and $\odot$ is the Hadamard product 12

\footnotetext{
${ }^{12}$ The parameters of equation (3) are estimated by ordinary least squares. Judson and Owen (1999) report severe negative bias for the autoregressive parameters of dynamic panel regressions due to the small time-series dimension even when $T=30$. The potential negative bias of autoregressive parameters has implications
} 
Bank-specific parameters mainly reflect different business models and the resulting differences in aversion for funding liquidity risk.

The solvency-liquidity nexus may appear in different forms; I test for the direct effect of solvency risk on funding liquidity using SRISK (section 3.1) and alternative solvency risk measures (section 3.2), and for the interaction between profitability and solvency risk in predicting the short-term balance sheet (section 3.3). Then, I test the robustness of the solvency-liquidity nexus in section 3.4 .

\subsection{Testing the Solvency-Liquidity Nexus Using SRISK}

The estimates of the interaction parameters $(\delta)$ of equation (3), where $x_{i t}=S R I S K_{i t} / T A_{i t}$, are reported in table 1 (column 1). This table reveals the Granger causality of solvency risk on the short-term balance sheet, where banks with a larger expected capital shortfall hold less short-term debt in the next quarter; the estimates suggest that a positive unit shock on the ratio of SRISK to total assets produces a -1.102 percent shock on the short-term funding of the bank.

This result supports the theoretical literature explaining bank runs based on the strength of the bank's fundamentals (Allen and Gale 1998; Diamond and Rajan 2005, etc.) and describing the interaction between liquidity and solvency problems of banks (Diamond and Rajan 2005; Morris and Shin 2008; Rochet and Vives 2004). The results also give empirical support to the recent speeches by Carney (2013) and Tarullo (2013) explaining that the repair of banks' balance sheet (i.e., higher capital levels) gives investors and creditors the confidence to continue to provide funding to banks.

From table 1, we also note that short-term assets do not react to solvency risk or short-term funding shocks, suggesting that banks are not able to adjust their stock of short-term assets to solvency risk or short-term funding conditions in a timely fashion. It also reflects a liquidity hoarding tendency of banks where banks prefer to sell long-term assets to repay short-term creditors. Banks prefer to hold the short-term assets for precautionary reasons or for investing in

for the stationarity of the endogenous variables of the panel regression. Running the regressions in first differences does not, however, qualitatively change the results on the $\delta$ parameter estimates. 


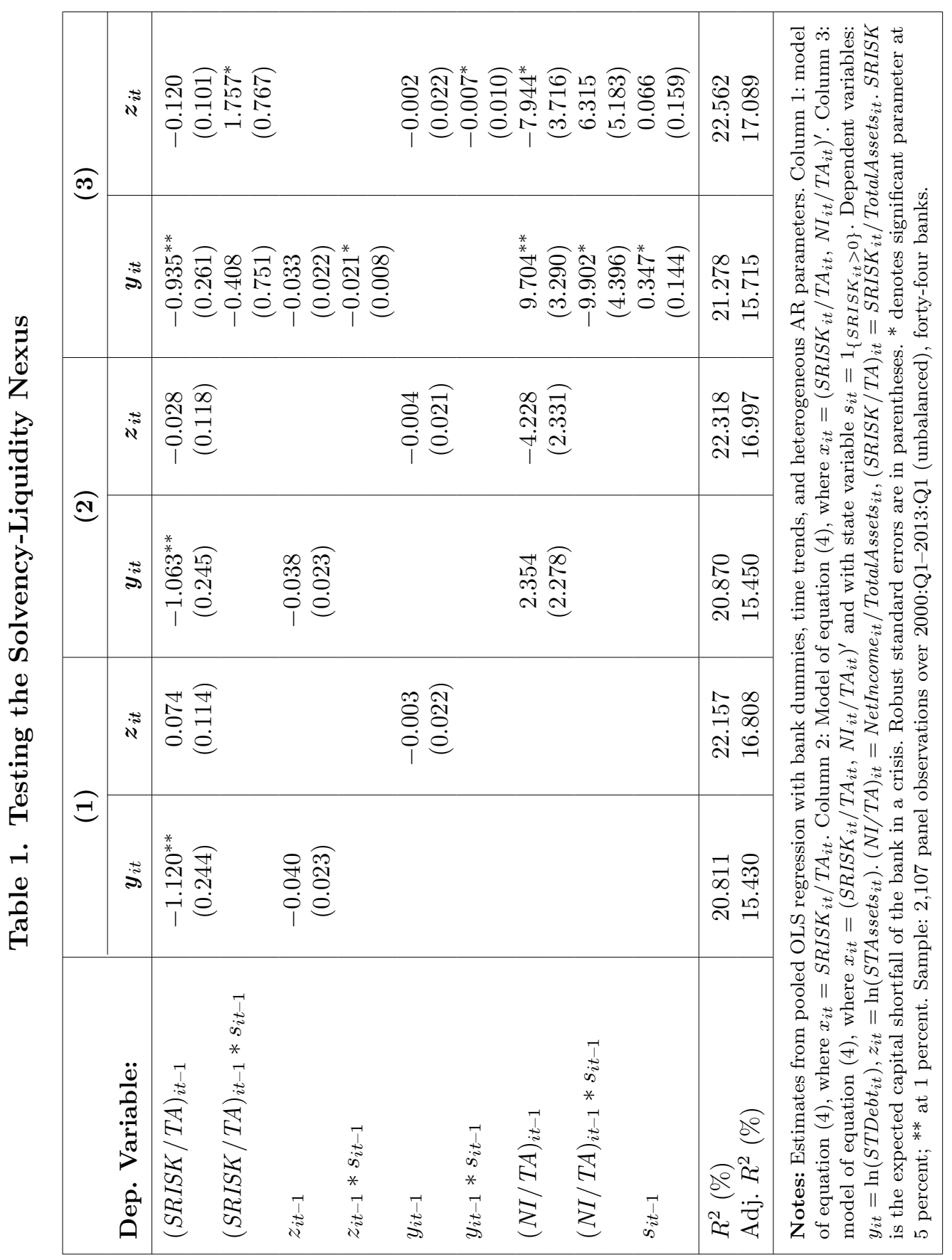


fire-sale assets of other financial institutions that are expected to generate high future returns (Acharya, Shin, and Yorulmazer 2009).

"Reverse causality" tests (in appendix 3) indicate that a higher exposure to short-term debt has a positive impact on the capital shortfall SRISK. Therefore, the interaction between solvency and the short-term balance sheet is asymmetric; higher solvency risk limits the access of the firm to short-term funding, but a firm with more short-term debt has a higher risk of insolvency in a crisis. The second finding is, however, harder to interpret as a causal relationship, as short-term debt is more likely to be endogenous than solvency risk. I therefore concentrate on the first finding: banks with higher solvency risk are penalized by the market in their access to short-term debt.

\subsection{Testing Alternative Solvency Risk Measures}

I report the tests of alternative measures of solvency risk to predict the short-term balance sheet $\left(y_{i t}\right.$ and $\left.z_{i t}\right)$ in table 2, controlling for the market-to-book ratio, as the regression includes both accounting and market variables. Columns $1-5$ show the individual impact of each measure. From this table, the regulatory capital ratios ( $T 1 C R$ and $T 1 L V G R)$ do not appear to be related to either side of the short-term balance sheet. Market measures of risk like the realized quarterly volatility are significant (at 5 percent) to predict short-term assets, but this result does not hold in the regression including all solvency risk factors (column 6). Then, the sensitivity of the bank's return to market shocks measured by the dynamic conditional beta (DCB) of Engle (2012), and the contribution of the bank to systemic risk measured by the delta CoVaR of Adrian and Brunnermeier (2010) are not significant drivers of the short-term balance sheet either. When all solvency risk factors are included in the regression (column 6), only SRISK per unit of asset and the market-to-book ratio are significant at the 1 percent level to predict the short-term debt level of banks.

The results of table 2 suggest that not all solvency risk factors can predict the shocks in the short-term balance sheet of banks. A bank with higher solvency risk in isolation does not necessarily get restricted access to short-term funding. However, banks lose shortterm funding when they are expected to be insolvent in a systemic crisis. An explanation for this observation is based on the liquidation 


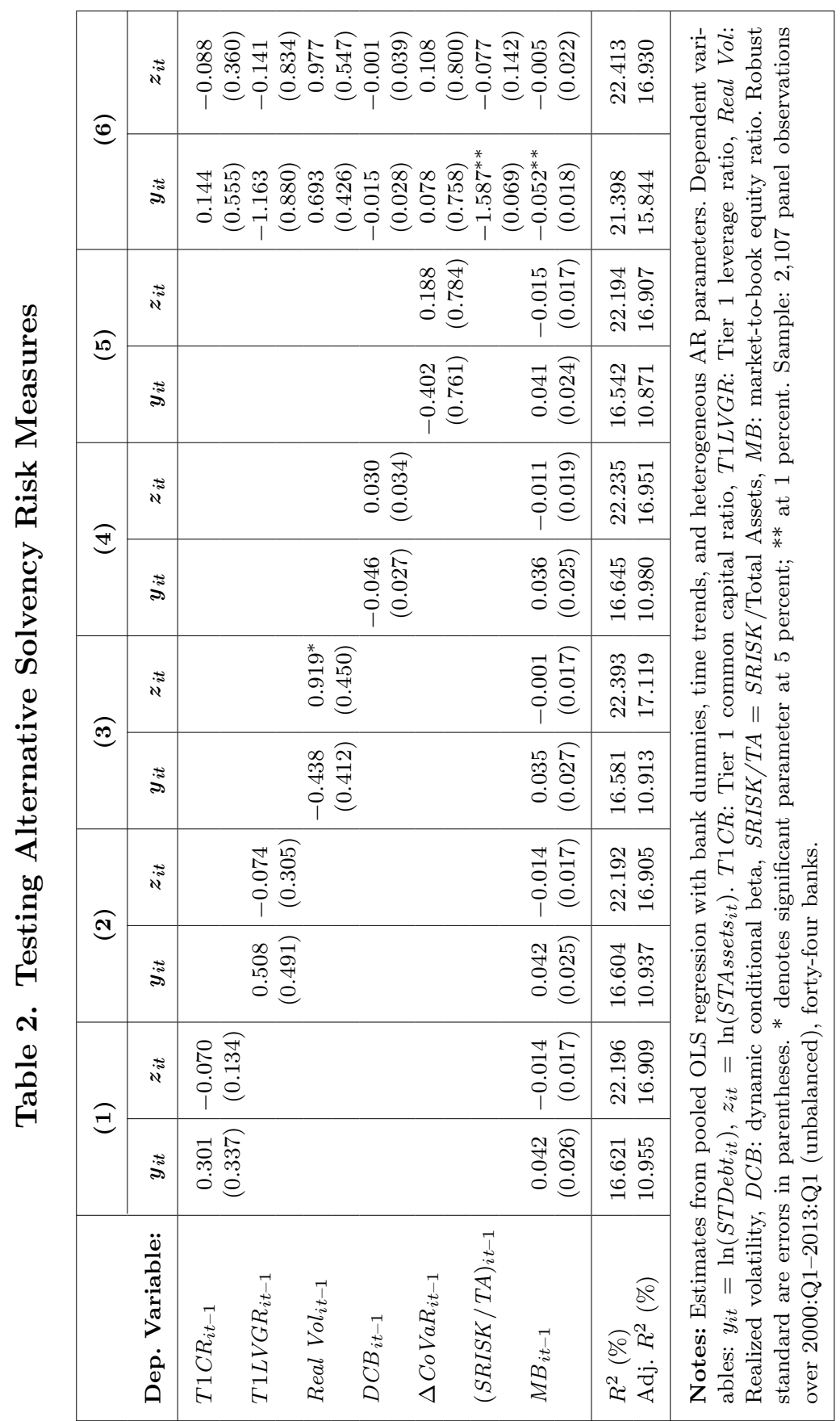


costs of a firm's illiquid assets in a crisis. Shleifer and Vishny (1992) show that when a firm is individually in distress, its liquidation costs are not as high because the firm can find buyers in the same industry who value its illiquid assets at a price close to their value in best use. In a crisis, however, the potential buyers in the industry will likely also meet difficulties in obtaining funding and will not be able to buy those assets. The firm will then have to sell its illiquid assets to less specialized buyers outside the industry at a higher liquidation cost.

A bank that is expected to be insolvent in a crisis will be facing high liquidation costs and will consequently not be able to raise cash. Creditors who anticipate this based on publicly available data (such as those used to derive SRISK) will run from the bank, as they expect the bank will not be able to repay them. The liquidation costs during the 2008 financial crisis were exacerbated by the huge gap between short-term assets and short-term debt observed in section 2. As a result, banks had no choice but to sell illiquid assets to repay creditors when losing access to short-term funding.

In-sample fit criteria show the higher performance of SRISK in table 3 (first column) in predicting short-term funding; the adjusted $R^{2}$ is 15.7 percent compared with an adjusted $R^{2}$ around 11 percent for the regressions with the alternative solvency risk measures of table 213 In order to identify what works so well in SRISK to predict the short-term funding of banks, table 3 also reports the estimates of the different components of SRISK highlighted in equation (2). The table shows that the improvement in in-sample fit comes from the ratio of market capitalization to total assets $(M V / T A)$ rather than from the long-run marginal expected shortfall (LRMES) or the quasi-market leverage $(L v g)$. The main difference between $L v g$ and the ratio $M V / T A$ is a different combination of book and market values; the ratio $M V / T A$ is the product of the book leverage ratio $\left(T 1 L V G R_{i t}\right)$ and the market-to-book ratio $\left(M V_{i t} / B V_{i t}\right)$

$$
\frac{M V_{i t}}{B V_{i t}}=\frac{B V_{i t} *\left(\frac{M V_{i t}}{B V_{i t}}\right)}{T A_{i t}} \simeq T 1 L V G R_{i t} *\left(\frac{M V_{i t}}{B V_{i t}}\right),
$$

\footnotetext{
${ }^{13}$ Note that all reported $R^{2}$ are on the first differences $\left(w_{i t}-w_{i t-1}\right)$. The $R^{2}$ of levels $\left(w_{i t}\right)$ are very high (around 90 percent) given the bank-specific constant, trend, and autoregressive parameters.
} 


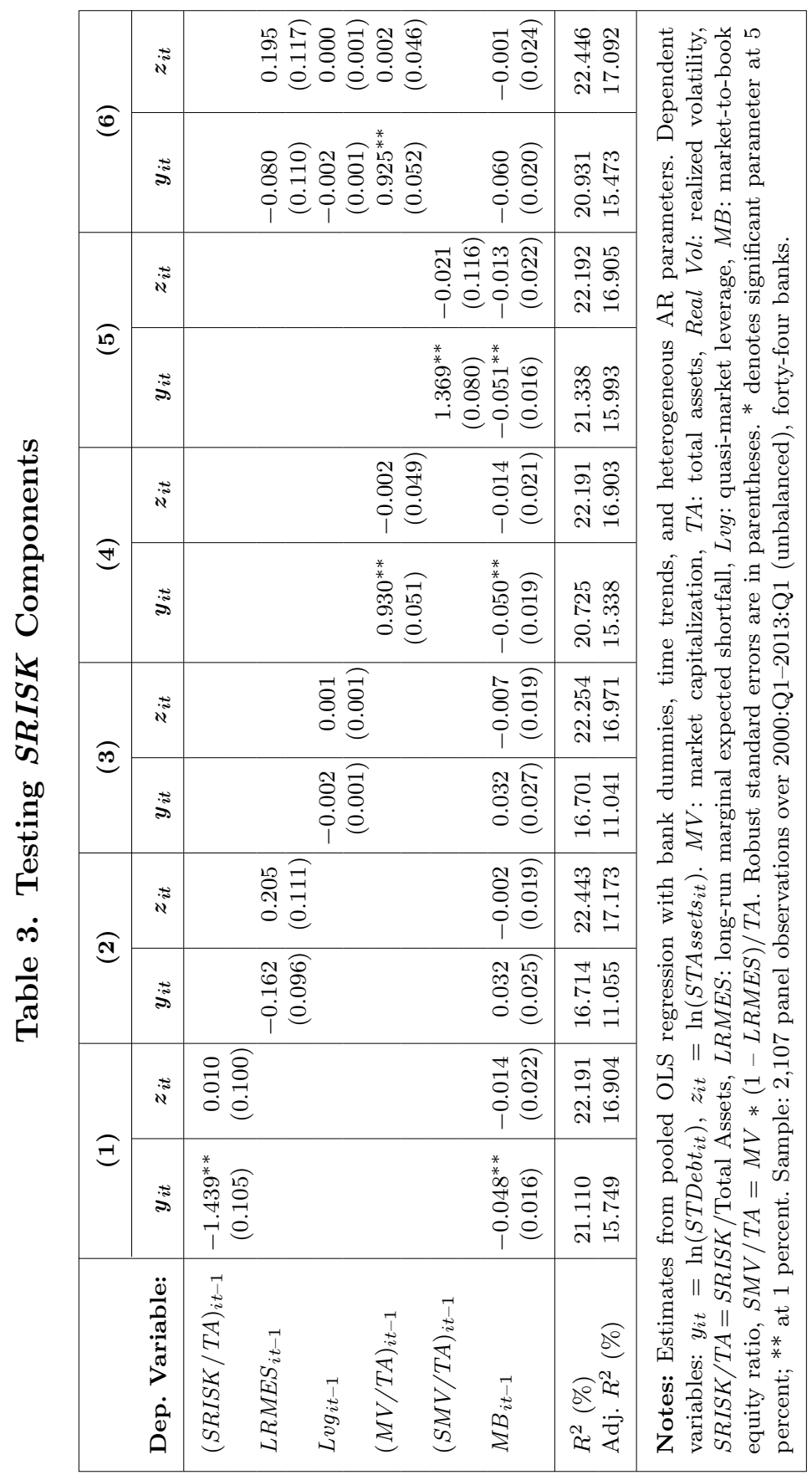


whereas $L v g_{i t}=1+\frac{D_{i t}}{M V_{i t}}$ is not a function of the book leverage ratio. Market values are expected to reflect liquidity problems of banks, as they incorporate information about both solvency and liquidity risks. Therefore, any measure based on market values is not a "pure" solvency risk measure. The fact that the ratio $M V / T A$ is a function of the book leverage ratio $\left(T 1 L V G R_{i t}\right)$ - a "pure" solvency risk measure - appears to be a crucial element in predicting short-term funding; it makes this ratio significant in the solvency-liquidity interaction compared with other solvency risk measures like the distance to default, which is an inverse function of market leverage $(\mathrm{Lvg})$ and firms' assets volatility. The results of table 3 indeed suggest that both the book leverage ratio - informing about "pure" solvency risk - and the market-to-book ratio - informing about how fast the market values fall compared with book values - are important factors explaining banks' access to short-term funding. The ratio $M V / T A$ is highly correlated to the book leverage ratio (0.91) and less correlated to the market-to-book ratio (0.44); solvency risk, amplified by market shocks, explains banks' access to short-term funding, and neither the market-to-book or the leverage ratio taken separately, nor their linear combination predict short-term funding.

The modest improvement in fit due to the downside risk of the bank in a crisis LRMES (0.66 percent increase of adjusted $R^{2}$ from column 4 to column 5 , table 3 ) is consistent with the sample period that contains several episodes of market stress. In a crisis, everything is already a function of the aggregate shock. However, measuring the downside risk is important preemptively; I find increasing out-ofsample forecasting errors when $M V / T A$ is employed in equation (3) instead of $S R I S K / T A$ for predicting the short-term balance sheet of banks during the European sovereign debt crisis (especially with the dynamic forecasting exercise of section 4).

\subsection{Interaction between Solvency and Profitability}

In Perotti and Suarez (2011), both liquidity risk and profitability are increasing functions of the short-term debt level of the bank. A bank will indeed demand more short-term funding when it finds profitable investment opportunities. Its liquidity risk will also increase, as its short-term debt will be invested in long-term profitable assets. The impact of the profitability of the bank measured by its net income 
divided by total assets is found to be positive on short-term debt and negative on short-term assets in table 1 (column 2), but these parameters are not significant at the 5 percent level.

The parameters of equation (3) are, however, expected to vary with the state of the bank and/or the aggregate liquidity conditions. In good times, short-term funding and short-term assets are the result of management decisions and are driven by demand factors. As mentioned, banks with profitable opportunities will demand more short-term funding. In bad times, supply factors determine how much short-term debt a bank can raise, and the short-term assets adjust accordingly. One way to disentangle supply and demand effects on the bank characteristics is to augment equation (3) with a state variable,

$$
w_{i t}=\alpha_{i}+\phi_{i} \odot w_{i t-1}+\theta_{i} t+\delta^{\prime} x_{i t-1}+\gamma^{\prime} x_{i t-1} * s_{t-1}+\omega s_{t-1}+\varepsilon_{i t},
$$

where the state variable $s_{t}$ could be a bank characteristic or a common factor. For example, Cornett et al. (2011) use the TED spread (the difference between the three-month LIBOR rate and the Treasury-bill rate) to reflect the change in the management of liquidity risk exposures of banks during the financial crisis 14 In table 1 (column 3), I show that a good candidate for the state variable is simply a dummy variable equal to one when SRISK is positive $\left(s_{i t}=1_{\left\{S R I S K_{i t}>0\right\}}\right)$, i.e., when the bank is expected to have a capital shortfall in a crisis.

This distinction between states where SRISK is positive or negative appears to be important when measuring the effect of the profitability of the bank on its short-term balance sheet. Indeed, a bank with a higher net income has greater access to short-term funding, while it does not hold as much in liquid assets. In table 1 , this beneficial effect of the bank's profitability on its short-term balance sheet appears to be true only when the bank's SRISK is negative, i.e., when the bank is adequately capitalized to survive a crisis $\left(s_{i t}=0\right)$. When the bank is expected to be capital constrained in a crisis $\left(s_{i t}=1\right)$, the effect of profitability on its balance sheet disappears $(\delta+\gamma \simeq 0)$, and only solvency risk predicts the short-term

\footnotetext{
${ }^{14}$ The TED spread is, however, not significant to predict the short-term balance sheet for the sample considered in this paper (cf. appendix 4).
} 
debt of the bank. Therefore, the solvency-liquidity nexus appears to be exacerbated for capital-constrained banks; for these banks, only solvency risk explains access to short-term debt.

\subsection{Robustness of the Solvency-Liquidity Nexus}

\subsubsection{Robustness to the TARP}

On October 14, 2008, the U.S. government announced a series of measures - the Troubled Asset Relief Program (TARP) - to restore financial stability. Under the TARP, the Treasury Department launched the Capital Purchase Program (CPP) and the Federal Deposit Insurance Corporation (FDIC) launched the Temporary Liquidity Guarantee Program (TLGP). Treasury injected $\$ 205$ billion in capital into banks under the CPP by buying warrants, common shares, and preferred shares 15 Under the TLGP, the FDIC allowed financial institutions to retain and raise funding by giving a guarantee on existing non-interest-bearing transaction accounts and certain newly issued senior unsecured debt. Data on the amount and maturity of total unsecured debt issued by banks and guaranteed by the FDIC are publicly available 16

It is possible to derive the hypothetical amount of short-term debt a bank would have had if it had not benefited from government guarantees. The solvency-liquidity nexus estimates hardly change when TLGP funding is not taken into account. It is, however, difficult to project this scenario on the other variables (SRISK and short-term assets), as it requires knowing where TLGP funding was invested and how markets would have reacted in this scenario.

\subsubsection{Robustness of the Solvency-Liquidity Nexus to Common Factors}

The short-term balance sheets of firms are expected to co-move according to the aggregate liquidity conditions. To capture these common effects, I consider the macroeconomic and financial factors that are used in Fontaine and Garcia (2012) to relate to their

\footnotetext{
${ }^{15}$ See http://www.treasury.gov/initiatives/financial-stability/TARP-Programs/ bank-investment-programs/cap/Pages/overview.aspx.

${ }^{16}$ See http://www.fdic.gov/regulations/resources/TLGP/index.html.
} 
factor measuring the value of funding liquidity. The sensitivity of the short-term balance sheet to the common factors is tested in appendix 4 .

I test the robustness of the solvency-liquidity nexus to the presence of common factors in

$$
w_{i t}=\alpha_{i}+\phi_{i} \odot w_{i t-1}+\theta_{i} t+\lambda^{\prime} g_{i t-1}+\beta^{\prime} f_{t-1}+\varepsilon_{i t},
$$

where $w_{i t}=\left(y_{i t}, z_{i t}\right)^{\prime} ; g_{i t}$ is a $((2 * K+1) \times 1)$ vector stacking $x_{i t}, x_{i t} * s_{i t}$, and $s_{i t}$ in a single column; $\lambda$ is a $((2 * K+1) \times 2)$ vector containing the $\delta, \gamma$, and $\omega$ parameters; and $f_{t}$ is a vector of macroeconomic and financial factors 17

Chudik and Pesaran (2013) propose an alternative modeling strategy based on the Common Correlated Effects (CCE) of Pesaran (2006), where the unobserved common factors are proxied by the cross-sectional averages of the dependent variable and the regressors

$$
w_{i t}=\alpha_{i}+\phi_{i} \odot w_{i t-1}+\theta_{i} t+\lambda^{\prime} g_{i t-1}+\sum_{l=0}^{1} \varphi_{l}^{\prime} \bar{w}_{t-l}+\kappa^{\prime} \bar{g}_{t-1}+\varepsilon_{i t},
$$

where $\bar{w}_{t-l}=N^{-1} \sum_{i=1}^{N} w_{i t-l}$ and $\bar{g}_{t}=N^{-1} \sum_{i=1}^{N} g_{i t}$.

The estimation results of equation (5) and equation (6) are reported in appendix 4 (table A4). The fit improves considerably when common factors are included. The best in-sample performance is found with the CCE model for all elements of $w_{i t}$. However, the CCE model counts a contemporaneous factor (average of the dependent variable), while the model with macro and financial factors only includes lagged factors. The macrofinancial model is therefore more convenient for forecasting, and the loss of in-sample fit is relatively small compared with the CCE model.

The solvency-liquidity nexus holds when I control for crosssectional dependence. The interaction term between the profitability and SRISK is, however, not as important (not significant at the 5 percent level).

\footnotetext{
${ }^{17}$ Note that common factors do not necessarily need to be lagged, but this allows for the derivation of one-step-ahead forecasts for $w_{i t}$ without specifying a model for the common factors.
} 


\subsubsection{Short-Term Debt Components and Fixed Effects}

The different components of short-term debt (repos, uninsured deposits, commercial papers, etc.) have very different characteristics and may not react to solvency risk with the same magnitude. Table A5 in appendix 4 reports the parameter estimates of equation (3) where the dependent variable in each column is a different component (in logarithm) of the short-term debt available from FR 9-YC reports. SRISK predicts most of the components of the short-term debt; it is significant at the 1 percent level for wholesale funding (federal funds, repos, and commercial papers) and at the 5 percent level for retail funding (uninsured time deposits and foreign office deposits).

Finally, an important result is that $S R I S K$ is only related to the short-term part of the balance sheet and does not predict long-term leverage. Table A6 in appendix 4 shows that the long-term balance sheet is not sensitive to SRISK. The long-term debt only reacts to short-term assets and the flows in long-term assets. Other robustness checks (not reported in this paper) show that the interaction between solvency and liquidity remains with homogenous dynamic parameters $\left(\phi_{i}=\phi, \forall i\right)$, with homogenous trend parameters $\left(\theta_{i}=\theta, \forall i\right)$, without trend $\left(\theta_{i}=0, \forall i\right)$, and when a break in 2008:Q4 is included in the trend. These results tend to confirm the robustness of the solvency-liquidity nexus. In the next section, I test for the out-ofsample forecasting performance of the solvency-liquidity nexus in predicting the short-term balance sheet of banks.

\section{Forecasting the Short-Term Balance Sheet}

To test for the out-of-sample predictive performance of the solvencyliquidity nexus, I conduct two forecasting exercises. Both exercises are based on a fixed estimation period from 2000:Q1 to 2010:Q4 to forecast the balance sheet of banks over the four quarters of 2011. The information is updated each quarter in the one-stepahead forecasts $\left(\hat{w}_{i t+1 \mid t}\right)$, while there is no information update in the dynamic forecasts $\left(\hat{w}_{i t+h \mid t}\right)$. The out-of-sample period corresponds to the European sovereign debt crisis. Funding conditions were not as tight as during the financial crisis in the United States, but the total 
decline of $\$ 161$ billion in short-term funding of U.S. banks during this period indicates potential liquidity stress for some banks.

The root mean square forecasting error (RMSFE) of the onestep-ahead forecasting exercise is reported in table 4. In this table, $I$ report the RMSFE of the short-term debt and short-term assets individually (panels $\mathrm{A}$ and $\mathrm{B}$ ), as well as the RMSFE of their difference (panel C). As already mentioned, the liquid asset shortfall is a measure of the exposure of banks to funding liquidity risk; the wider the gap in the short-term balance sheet, the more vulnerable the bank to runs. As this paper studies the liquidity-solvency nexus of banks, I also report the RMSFE of this liquid asset shortfall for capital-constrained banks (panel D) vs. adequately capitalized banks (panel E).

Four models are considered: a univariate autoregressive model (AR), the model of equation (3) with bank characteristics (BC), the model of equation (4) that allows for the interaction of bank characteristics with the state variable $s_{i t}=1_{\left\{S R I S K_{i t}>0\right\}}$ (INT), and the model including all these features together with the macroeconomic and financial factors (equation (5)) (CF).

The assumption on the trend appears to be the most important model characteristic to impact forecasting errors. To check for the robustness of the forecasting results, I report the RMSFE of these models for different trend assumptions (heterogeneous trends, homogenous trend, no trend, and a break in the homogenous trend in 2008:Q4).

For the one-step-ahead forecasts, the best model is the dynamic model that accounts for the interaction of bank characteristics with SRISK (INT) and that assumes a break in the trend in the fourth quarter of 2008. When the trend parameters are constant over time, the model with common factors $(\mathrm{CF})$ performs the best for the liquid asset shortfall, as common factors reflect the changing aggregate funding conditions after the financial crisis. In the last three columns of table 4, I report the increase in RMSFE when a particular bank variable is not included in the $\mathrm{BC}$ model. This table shows that omitting SRISK increases the forecasting errors of the liquid asset shortfall considerably, particularly for capital-constrained banks during 2011. However, the model with bank characteristics (BC) or the interaction with solvency risk (INT) does not improve the forecasts of adequately capitalized banks. 


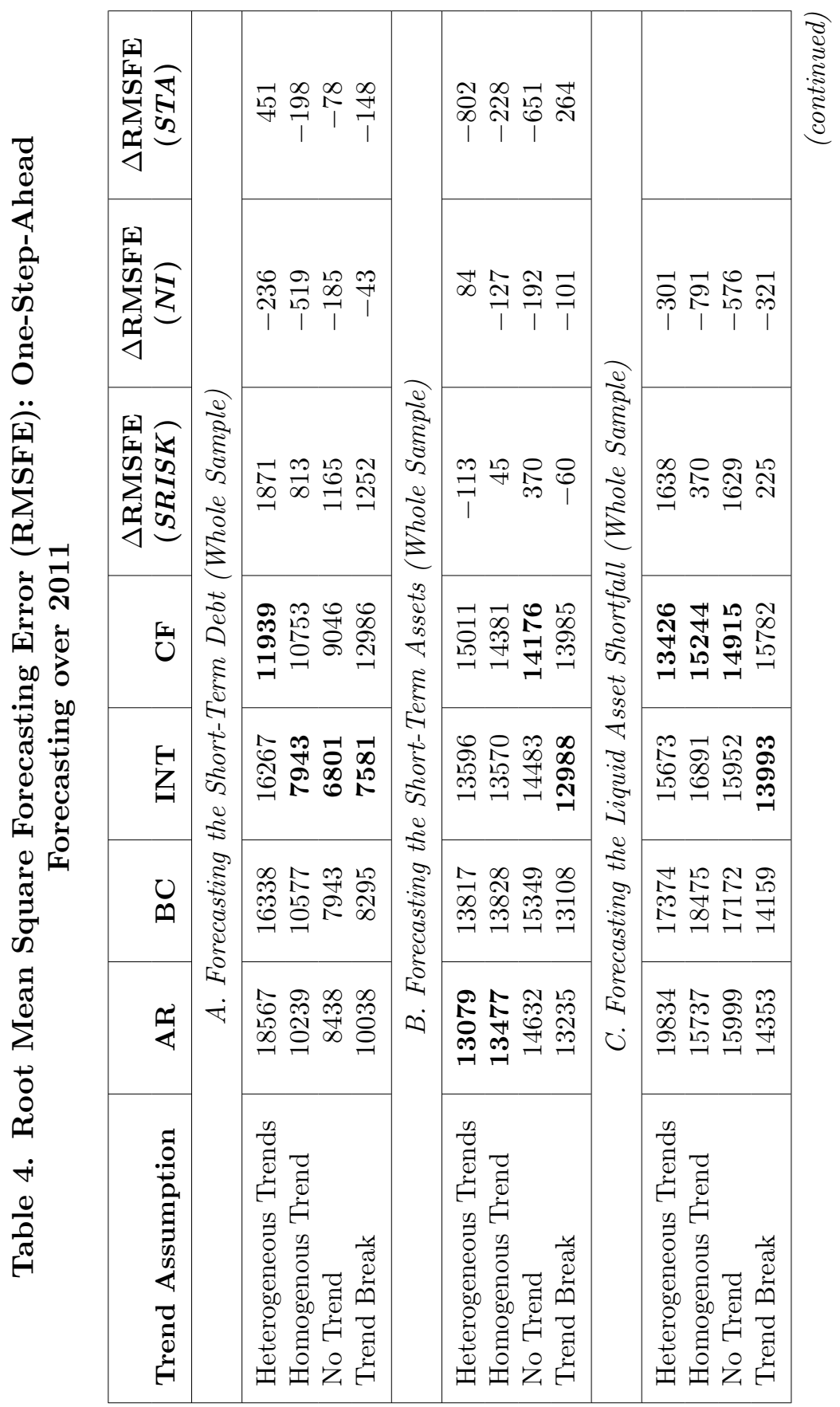




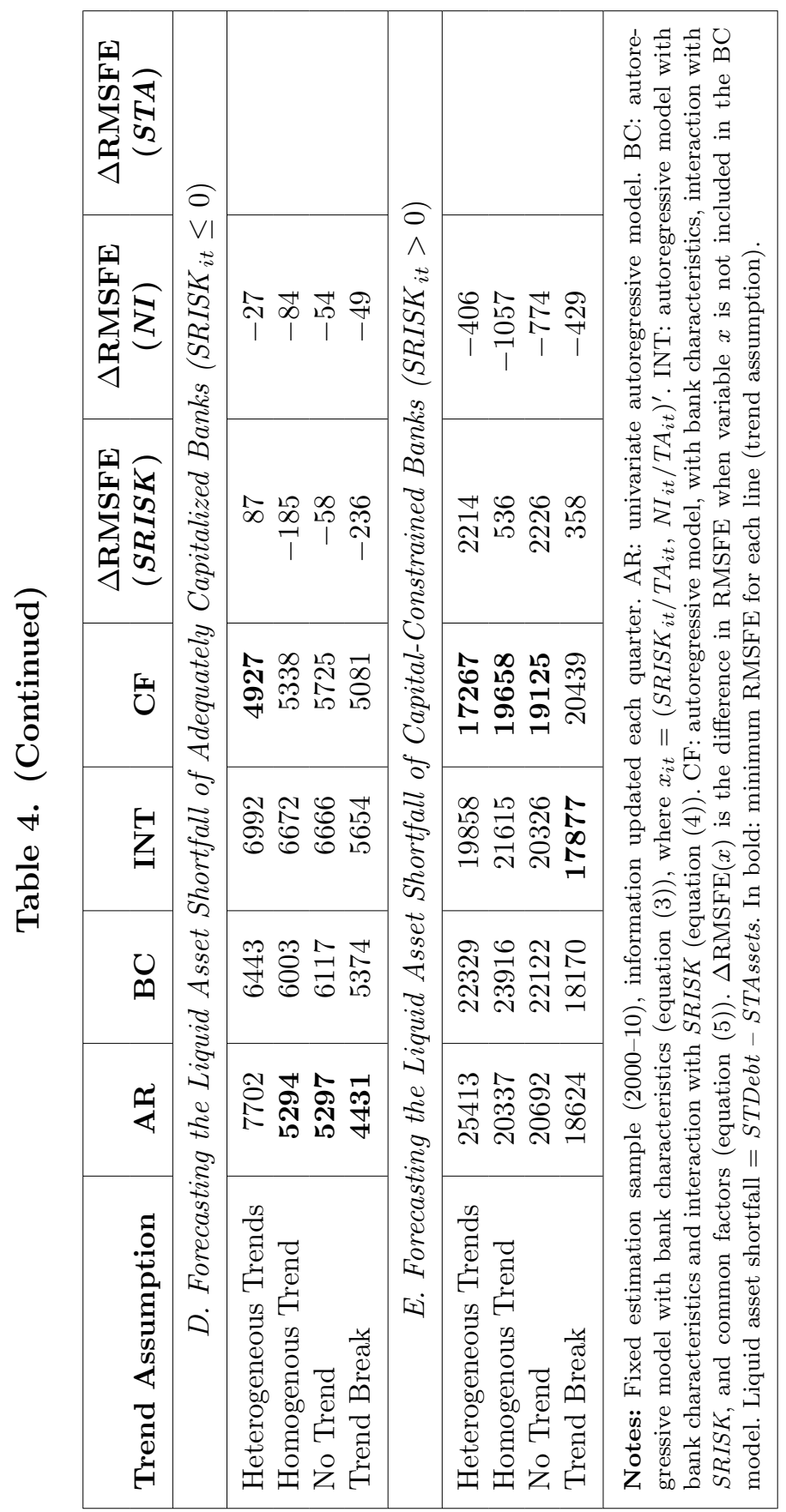


I obtain very similar results for the dynamic forecasts and therefore do not report their RMSFE. Note that the RMSFE of dynamic forecasts are larger than the errors of one-step-ahead forecasts due to the absence of information updates over the forecasting horizon. The model with interaction with SRISK (INT) and a break in the trend after the financial crisis is also the preferred model according to the RMSFE of dynamic forecasts. The cross-sectional average dynamic forecasts obtained with this model for the short-term balance sheet levels and flows over 2011:Q1-2013:Q1 are illustrated in figure 5A. It turns out that the model is outstanding at forecasting short-term financing flows but is less successful at forecasting short-term asset flows, which are not sensitive to the factors considered in the model.

In figure 5B, I show the average dynamic forecasts of the liquid asset shortfall across all banks, as well as for the sub-samples of capital-constrained vs. adequately capitalized banks. As mentioned in the Introduction, the liquid asset shortfall of capital-constrained banks spiked in the first quarters of 2007 and suddenly dropped afterwards due to the sudden freeze of short-term funding markets. In the first quarter of 2011, the average liquid asset shortfall of capital-constrained banks became negative; capital-constrained firms are less exposed to funding liquidity risk than adequately capitalized banks for the first time over the sample period. The model predicts this reversal in the solvency-liquidity nexus and predicts well the average excess of liquidity of capital-constrained banks during this period.

\section{Conclusion}

This paper reveals the empirical solvency-liquidity nexus of banks. While the interaction between solvency and liquidity has been well studied in the theoretical economic literature, this relationship tends to be omitted in the new capital and liquidity regulatory standards introduced under Basel III. In this paper, I test the solvency-liquidity nexus by examining the short-term balance sheet and the solvency risk measures of a sample of U.S. bank holding companies over 2000-13.

I find that the expected capital shortfall of a bank in a crisis (SRISK) predicts how much short-term funding the bank has access to. This result appears to be strong under many robustness checks 


\section{Figure 5. Forecasting the Short-Term Balance Sheet over 2011:Q1-2013:Q1}

\section{A. Short-Term Balance Sheet Levels and Flows}
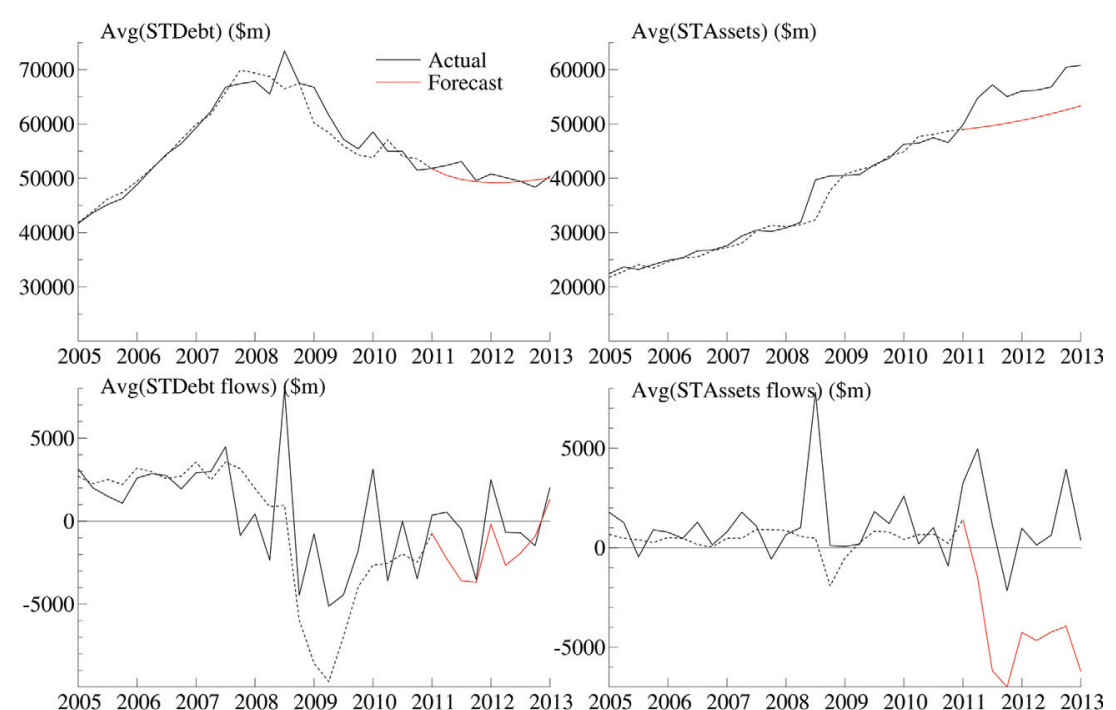

\section{B. Liquid Asset Shortfall}

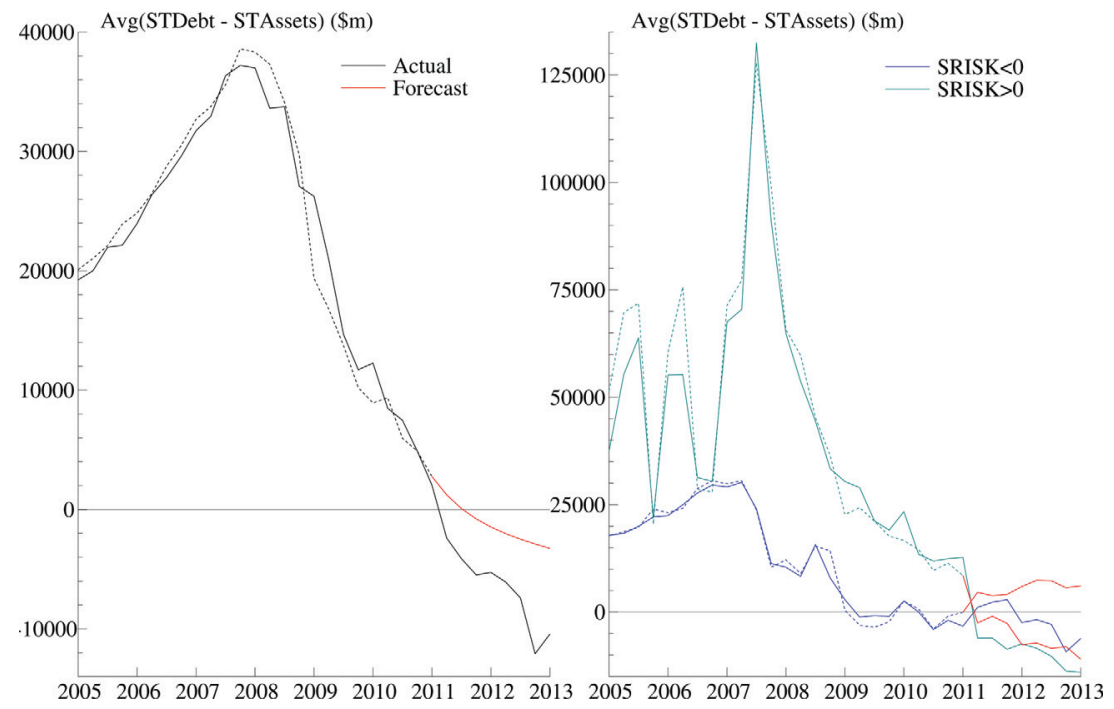

Notes: The figure shows dynamic forecasts over 2011:Q1-2013:Q1 - model with SRISK as a state variable (equation (4), break in trend). 
and supports the theoretical models of the interaction between solvency and liquidity risks and its amplification (aggregate) effects leading to systemic risk.

Importantly, not all solvency risk measures predict the bank's access to short-term debt. The expected capital shortfall SRISK interacts well with the level of short-term funding of the bank compared with other solvency risk measures because (i) it is a measure of the bank's exposure to aggregate risk, and (ii) it combines both book and market values. Suppliers of liquidity are mostly concerned with the vulnerability of the bank to an aggregate crisis due to the high liquidation costs the distressed bank will face in the presence of fire sales. When the crisis happens, "pure" solvency risk (measured by the tier 1 leverage ratio) amplified by market shocks explains the bank access to short-term funding.

The expected capital shortfall of the bank under stress also interacts with its profitability in determining its short-term balance sheet. While a profitable bank gets greater access to short-term funding and does not hold as much in liquid assets, the impact of the bank's profitability on its liquidity profile tends to disappear when the bank is expected to be insolvent in a crisis.

The solvency-liquidity nexus provides useful information for forecasting the short-term financing flows during 2011 (European sovereign debt crisis). I show that the forecasting errors of the liquid asset shortfall of banks increase considerably when the stressed solvency risk measure is not included in the regression.

Overall, the results of this paper suggest that the solvencyliquidity nexus should be accounted for when designing liquidity and capital regulations, where macroprudential regulation of funding liquidity risk would be a combination of both liquid assets requirements and capital requirements. This paper suggests that maintaining the capitalization of the banking sector reduces systemic risk not only by addressing solvency risk problems of banks in a crisis but also by attenuating the solvency-liquidity nexus that makes banks particularly vulnerable to an aggregate crisis. Higher capital requirements for systemically important institutions serve a dual purpose: they act as a loss-absorbing buffer when banks' asset values deteriorate, and by improving banks' robustness to an aggregate crisis, they ensure the confidence of creditors to continue to provide funding to the banks. 


\section{References}

Acharya, V., C. Brownlees, R. Engle, F. Farazmand, and M. Richardson. 2010. "Measuring Systemic Risk." In Regulating Wall Street: The Dodd-Frank Act and the New Architecture of Global Finance, ed. V. Acharya, T. Cooley, M. Richardson, and I. Walter, chapter 4. John Wiley \& Sons.

Acharya, V., R. Engle, and M. Richardson. 2012. "Capital Shortfall: A New Approach to Rankings and Regulating Systemic Risks." American Economic Review: Papers and Proceedings 102 (3): $59-64$.

Acharya, V., H. Shin, and T. Yorulmazer. 2009. "Endogenous Choice of Bank Liquidity: The Role of Fire Sales." Working Paper No. 376, Bank of England.

Acharya, V., and S. Viswanathan. 2011. "Leverage, Moral Hazard, and Liquidity." Journal of Finance 66 (1): 99-138.

Acharya, V., and T. Yorulmazer. 2008. "Cash-in-the-Market Pricing and Optimal Resolution of Bank Failures." Review of Financial Studies 21 (6): 2705-42.

Adrian, T., and M. Brunnermeier. 2010. "CoVaR." Staff Report No. 348, Federal Reserve Bank of New York.

Afonso, G., A. Kovner, and A. Schoar. 2011. "Stressed, Not Frozen: The Federal Funds Market in the Financial Crisis." Staff Report No. 437, Federal Reserve Bank of New York.

Aikman, D., P. Alessandri, B. Eklund, P. Gai, S. Kapadia, E. Martin, N. Mora, G. Sterne, and M. Willison. 2009. "Funding Liquidity Risk in a Quantitative Model of Systemic Stability." Working Paper No. 372, Bank of England.

Allen, F., and D. Gale. 1998. "Optimal Financial Crises." Journal of Finance 53 (4): 1246-84.

- 2000a. "Financial Contagion." Journal of Political Economy 108 (1): 1-33.

- 2000b. "Optimal Currency Crises." Carnegie-Rochester Conference Series on Public Policy 53 (1): 177-230.

- 2004. "Financial Intermediaries and Markets." Econometrica 72 (4): 1023-61.

Basel Committee on Banking Supervision. 2011. "Basel III: A Global Regulatory Framework for More Resilient Banks and Banking Systems." Bank for International Settlements (June). 
. 2013a. "Basel III: The Liquidity Coverage Ratio and Liquidity Risk Monitoring Tools." Bank for International Settlements (January).

—. 2013b. "Global Systemically Important Banks: Updated Assessment Methodology and the Higher Loss Absorbency Requirement." Bank for International Settlements (July).

Brownlees, C., and R. Engle. 2011. "Volatility, Correlation and Tails for Systemic Risk Measurement." Working Paper, New York University.

Carney, M. 2013. "Crossing the Threshold to Recovery." Speech given at a business lunch hosted by the CBI East Midlands, Darbyshire and Nottinghamshire Chamber of Commerce and the Institute of Directors, Nottingham, August 28.

Chudik, A., and H. Pesaran. 2013. "Common Correlated Effects Estimation of Heterogeneous Dynamic Panel Data Models with Weakly Exogenous Regressors." Working Paper in Economics No. 1317, University of Cambridge.

Cornett, M., J. McNutt, P. Strahan, and H. Tehranian. 2011. "Liquidity Risk Management and Credit Supply in the Financial Crisis." Journal of Financial Economics 101 (2): 297-312.

Das, S., and A. Sy. 2012. "How Risky Are Banks' Risk-Weighted Assets? Evidence from the Financial Crisis." IMF Working Paper No. $12 / 36$.

Diamond, D., and P. Dybvig. 1983. "Bank Runs, Deposit Insurance, and Liquidity." Journal of Political Economy 91 (3): 401-19.

Diamond, D., and R. Rajan. 2005. "Liquidity Shortages and Banking Crises." Journal of Finance 60 (2): 615-47.

- 2011. "Fear of Fire Sales, Illiquidity Seeking, and Credit Freezes." Quarterly Journal of Economics 126 (2): 557-91.

Drehmann, M., and K. Nikolaou. 2013. "Funding Liquidity Risk: Definition and Measurement." Journal of Banking and Finance 37 (7): $2173-82$.

Engle, R. 2012. "Dynamic Conditional Beta." Working Paper, New York University.

Fontaine, J.-S., and R. Garcia. 2012. "Bond Liquidity Premia." Review of Financial Studies 25 (4): 1207-54.

Gorton, G. 1988. "Banking Panics and Business Cycles." Oxford Economic Papers 40 (4): 751-81. 
Gorton, G., and A. Metrick. 2012. "Securitized Banking and the Run on Repo." Journal of Financial Economics 104 (3): 425-51.

Huang, X., H. Zhou, and Z. Haibin. 2012. "Systemic Risk Contributions." Journal of Financial Services Research 42 (1): 55-83.

Judson, R., and A. Owen. 1999. "Estimating Dynamic Panel Data Models: A Guide for Macroeconomists." Economics Letters 65 (1): $9-15$.

Morris, S., and H. Shin. 2008. "Financial Regulation in a System Context." Brookings Papers on Economic Activity 2008 (Fall): $229-61$.

Perotti, E., and J. Suarez. 2011. "A Pigovian Approach to Liquidity Regulation." International Journal of Central Banking 7 (4): 3-39.

Pesaran, H. 2006. "Estimation and Inference in Large Heterogeneous Panels with a Multifactor Error Structure. Econometrica 74 (4): 967-1012.

- 2007. "A Simple Panel Unit Root Test in the Presence of Cross-Section Dependence." Journal of Applied Econometrics 22 (2): $265-312$.

Rochet, J.-C., and X. Vives. 2004. "Coordination Failures and the Lender of Last Resort: Was Bagehot Right after All?" Journal of the European Economic Association 2 (6): 1116-47.

Shleifer, A., and R. Vishny. 1992. "Liquidation Values and Debt Capacity: A Market Equilibrium Approach." Journal of Finance 47 (4): 1343-66.

Tarullo, D. 2013. "Evaluating Progress in Regulatory Reforms to Promote Financial Stability." Speech given at the Peterson Institute for International Economics, Washington, DC, May 3. 